EESTI NSV TEADUSTE AKADEEMIA TOIMETISED.

FOOSIKA * MATEMAATIKA

ИЗВЕСТИЯ АКАДЕМИИ НАУК ЭСТОНСКОН ССР. ФИЗИКА * МАТЕМАТИКА

PROCEEDINGS OF THE ACADEMY OF SCIENCES OF THE ESTONIAN SSR.

PHYSICS * MATHEMATICS

$1986,35,2$

УДК $621.59 ; 535.8 ; 536.48$

В. КОРРОВНТС, М. ТРУММАЛ

\title{
РЕФРИЖЕРАТОР РАСТВОРЕНИЯ С ОПТИЧЕСКИМИ ОКНАМИ
}

v. KORROVITS, M. TRUMMAL. OPTILISTE AKENDEGA LAHUSTAMISKROOSTAAT

I. KORROVITS, M. TRUMMAL. DILUTION REFRIGERATOR WITH OPTICAL WINDOWS

\section{(Представил К. К. Ребане)}

Целесообразность проведения оптических измерений при температурах $3 \cdot 10^{-2}-3 \cdot 10^{-1} \mathrm{~K}$, получаемых в рефрижераторе растворения ${ }^{3} \mathrm{He}-{ }^{4} \mathrm{He}$, обусловлена, на наш взгляд, интересом к температурной зависимости физических процессов, изученных ранее при $T \geqslant 0,3 \mathrm{~K}$, в частности, времени жизни триплетного состояния автолокализованных экситонов [ $\left.{ }^{1}\right]$ или примесных центров $\left[{ }^{2}\right]$ в щелочногалоидных кристаллах, а также ширины фотохимически выжигаемого провала в неоднородно уширенных полосах спектров стекол $\left[{ }^{3,4}\right]$.

Авторами работы $\left[{ }^{5}\right]$ описан рефрижератор растворения, снабженный кварцевым световодом, подводящим световое излучение к образцу, прикрепленному к медному пальцу, который ввинчивается в нижний торец камеры растворения. Минимальная температура криостата составляла 140 мК, холодопроизводительность - 3 мкВт при 200 мК. Рефрижератор растворения использовался в $\left[{ }^{6}\right]$ для исследования скорости оптической дефазировки ионов $\mathrm{Nd}^{3+}$ в кремниевом волокне по методу фотонного эха при $T \geqslant 100$ мК. При этом объект находился вне камеры растворения, тепловой контакт между объектом и камерой осуществлялся с помощью теплопроводящей жировой смазки. Объект не охлаждался ниже 100 мК, очевидно, из-за недостаточного теплового контакта с камерой растворения.

Для оптических измерений нами был приспособлен рефрижератор растворения ${ }^{3} \mathrm{He}-{ }^{4} \mathrm{He}$, выпускаемый НПО «Гелиймаш» $\left[{ }^{7}\right]$. Его усовершенствованный вариант имеет два последовательно соединенных низкотемпературных теплообменника. Минимальная температура в режиме циркуляции составляет $40-45$ мК, в разовом режиме - 32 мК, холодопроизводительность - 46 мкВт при $100 \mathrm{мK}$, скорость циркуляции ${ }^{3} \mathrm{He}-$ до $1,5 \cdot 10^{-4}$ моль $\cdot \mathrm{c}^{-1}$.

В нашем криостате путь светового луча был вертикальным со дна криостата в камеру растворения через соосные прозрачные окна и слой сверхтекучего гелия. Центрирование вставки, гелиевого сосуда, азотного экрана и внешнего кожуха производилось на уровне разборных фланцев в нижней части криостата. -На оптическом тракте имелось 5 окон: на камере растворения $\varnothing 10$ мм, на вакуумной камере $\varnothing 10$ мм, на гелиевом сосуде $\varnothing 15$ мм, на азотном экране $\varnothing 23$ мм. на внешнем кожухе $\varnothing 24$ мм (рис. 1). Толщина окон 2 и 3 мм. Окно камеры растворения находится на расстоянии 19 см от окна на внешнем кожухе, апертурный угол $2 \psi=10^{\circ}$. Вводимый в криостат световой луч отражается от зеркала, расположенного за объектом.

Измерения, проведенные в оптическом криостате с ${ }^{3} \mathrm{He}\left[{ }^{8}\right]$, п़ока: 
Леода. При давлении $p \leqslant 1$ мм рт. ст. учитывалась поправка на термомолекулярную разность давлений согласно экспериментальным данным $\left[{ }^{9}\right]$. Проводимость термометров сопротивления измерялась с помощью моста РСB (фирма SHE, США) (точность 0,05\%) при рассеиваемой на термометре мощности не более $10^{-12}$ Вт. Температура камеры испарения рефрижератора регистрировалась термометром радиосопрогивления ТВО с $R_{300 \mathrm{~K}}=300$ Ом, а сопротивление его измерялось мостом сопротивления S-72D (ЧСCP). Регистрации показаний термометров мешали наводки от радиопомех, устранить которые удалось лишь частично. Из-за наводок погрешность в определении температуры камеры растворения термометрами сопротивления $\Delta T^{\prime} \leqslant 10 \%$.

При выборе материала для оптических окон нами были исследованы различные образцы. Измерения ИК-поглощения проводились в Институте физики АН УCCP в Киеве на ИК-спектрометрах UR-10 (ГДР) и FIS-3 («Hitachi», Япония) в интервале от 2 до 333 мкм. По поглощению ИК-излучения наиболее подходящим для окон является оптический фильтр СЗС-25.

Все окна за исключением окна на азотном экране были на индиевых уплотнениях. Окна приклеивались к цилиндрической медной трубке (толщина стенки 0,08 мм и длина трубки 10 мм) эпоксидным составом ДФМ-135. Окна на камере растворения и на вакуумной камере были из СЗС-25, остальные из кварца. Фильтр СЗС-25 имеет коэффициент пропускания $\tau_{\lambda}=0$ для $\lambda>920$ нм при толщине фильтра 2 мм и для $\lambda>800$ нм при толщине 4 мм $\left\lceil^{10}\right\rceil$. Поток ИК-излучения через окна рефрижератора не превышает $10^{-10}$ Вт. Расчет показывает, что при замене окон из СЗС-25 на окна из кварца поток ИК-излучения составляет $10^{-8}$ Вт [ $\left.{ }^{11}\right]$. Оптические измерения в криостате можно проводить в спектральном интервале от 0,2 до 4 мкм.

В криостате проводились измерения температурной зависимости ширины провала, выжигаемого фотохимически в $\mathrm{H}_{2}$-октаэтилпорфине в матрице полистирола, в интервале от 50 мК до $1,5 \mathrm{~K}\left[{ }^{12}\right]$.

Авторы выражают благодарность С. Т. Болдареву за усовершенствование криогенной системы рефрижератора, Г. А. Пучковской за проведение ИК-измерений, Г. Г. Лийдья за полезные советы и стимулирующие дискуссии.

\section{ЛИТЕРАТ У РА}

1. Лийдья $\Gamma$. Г., Соовик $T$. А. Тр. Ин-та физики АН ЭССР, 52, 53-70 (1981).

2. Hizhnyakov, V., Liidia, G.. Nagirnyi, V., Soovik, T., Zasubovich, S. Phys. status. solidi (b), 120, № 1, 105-115 (1983).

3. Гороховский А. А., Кикас Я. В., Пальм В. В., Ребане Л. А. Физ. твердого тела, 23, вып. 4, 1040-1047 (1981).

4. Thijssen, H. P. H., van den Berg, R. E., Völker, S. Chem. Phys. Lett., 103, № 1, $23-28$ (1983).

5. Журкин В. Г., Фрадков В. А., Филин Б. П.. Цховребов А. М. ФИАН, СССР. криогенный отдел. Препринт № 107. М., 1982.

6. Hegarty, I., Broer, M. M., Golding. B., Simpson, J. R., MacChesney, J. B. Phys. Rev. Lett., 51, № 22, 2033-2035 (1983).

7. Амамчян Р. Г., Болдарев С. Т., Калитин П. П., Мирославская Е. А., Оносовский

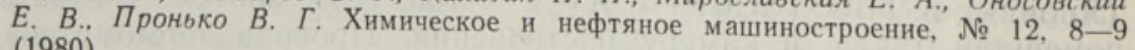
(1980).

8. Лийдья Г. Г.. Лыхмус А. Э., Нагел У. Х. ПТЭ. 26, № 1, 173-176 (1983).

9. Freddi, A., Modena, I. Cryogenics, 8, № 1, 18-23 (1968).

10. Стекло оптическое цветное. ГОСТ 9411-75. Каталог, М., Госстандарт, 1980. 11. Криксунов Л. 3. Справочник по основам ннфракрасной техникн, М., «Советское
радиов. 1978.

12. Гороховский А. А., Корровитс В. Х., Пальм В. В., Труммал М. А. Письма в ЖЭТФ, 42, № 6, 249-252 (1985). 